\title{
THE MACRO-MICRO FACTORS ANALYSIS ON THE EVALUATION SYSTEM OF THE GRADUATE STUDENTS' EDUCATION SERVICE TRADE
}

\author{
Jingwei Xu \\ University of Shanghai for Science and Technology, East China Normal University, \\ P.R.China \\ Shikun Gong \\ Nanjing Audit University Jinshen College, P.R.China \\ Li Shen \\ University of Shanghai for Science and Technology, P.R.China
}

\begin{abstract}
The service trade of international education is a profound reflection of the strength of competitiveness a nation's education has. Since China's accession to WTO, domestic education industry gradually started to present itself to the service trading market. Education service trade has greatly evolved with an increasing amount of education service import and export owing to such consumptions by Chinese students studying abroad. Graduate education in some developed countries is an early bird in this line of industry and has developed fully-fledged systems of its own over the years. Apart from what those systems have in common, different education systems and scales all have their own characters.

By absorbing the advanced experiences of the advanced education service trade, a path of development for the education service trade would be found, which is suitable to China's actual situation. In hope of finding a new path for the development of education service trade suitable for China's situation, advanced experience in the trade should be absorbed. In order to improve the status of the Chinese service trade and the export competitiveness, the frame of the trade's evaluation system should be constructed. These suggestions aim to contribute to the development of the education service.
\end{abstract}

Keywords: Education service trade, Evaluation System, graduate-students

\section{JEL code: A23}

\section{Introduction about the graduate students' education service trade in China}

"Education is the basis for a nation's grand design". Education concepts and scales are of great significance to the future of a country. The development of education has always been a driving force for political and economical progress in China. Under the heat wave of economical and educational globalization, this country's education service industry is confronting unprecedented opportunities as well as challenges. What China's education industry is facing is the way to connect to the international 
education market as soon as possible and to realize education industrialization and globalization after its accession to the WTO.

We can consider setting up a kind of evaluation system before putting forward measures in line with the actual situation and refine the essence according to each element from the evaluation system in order to improve the condition of graduate students' education service trade in China. Then the overall competitiveness of China's postgraduate education service trade could be improved.

\section{The macro-micro factors of the evaluation system}

As the research go deeper, it is in the opinion of the author that the following macro and micro factors have important effects on the export competitiveness of graduate student education services in our country; so hope that through analysis of these elements, a framework of an evaluation system for graduate scales and education service could be constructed. The system mainly consists of the following parts:

\subsection{Establishing a suitable language system of graduate students' education service trade}

Language is the foundation of all professional knowledge. It is generally divided into four scales, "native tongue", "general knowledge", "fluent communication" and "basic understanding". For graduate education service trade, graduate students from homeland and are taught in mother tongue have great advantage because most of them don't have language barrier. That is one big reason why the U.S. and U.K. are quite ahead of other countries in the graduate student services trade. Apart from graduates who major in languages will have a larger selection of courses, many local students majoring in other professional courses can save plenty of time preparation for language itself compared to foreign students with English as second language, such advantages in time and money are just obvious to see.

English is not only widely used in English-speaking countries but is also regarded as a lingua franca and the official language of many other countries. After British colonial period, English was promoted worldwide along with its culture, which resulted in the harvest of benefits in the early period of capitalism. The benefit has continued to grow until this day which might be hardly anticipated by the authorities at that time. The language advantage U.S. and U.K. have could reach out to the very outcome of the major options available for imported graduate consumers. The most direct result to this is that graduate education service in these countries are more competitive, its export volume larger in scale and amount. Meanwhile, English education is part of early education in many countries; students who go abroad for further education usually acquired excellent English skills before going. 


\subsection{Integrating internationalization and localization of graduate education mode}

The differences in historical and cultural background are the cause of imbalance in development and variability in form of graduate education development. In the course of developing graduate education services, the historical and cultural background as well as the progress and status of the economy should be taken into consideration referring to the progress mode of other countries. However, we shall not simply mimic their modes. The government and functional departments should be very cautious about the issue of education industrialization and the opening should not be fully drawn out at one time because it may run out of control and end up in awkwardness. The internationalization should be combined with localization. Yet their characteristics of education service trade should not be abandoned; the education services mode at home and abroad should be integrated to improve the competitiveness of graduate student services trade in the shortest time possible. Meanwhile, the education of intercultural competence is playing a more and more crucial role in contemporary society.

\subsection{The setting of short-term and long-term planning as well as establishment of policy planning of echelon in a political scale}

The guidance and support of a country's considerate policy can do much good on a particular industry. The government could make both short and long-term plans for graduate education industry. Short-term goals can help graduate education industry gain some education input in a short time; long-term planning can on the macro sense clarify the tendency of national policy, and ensure its continuity.

In addition, for ensuring the continuity of the policy, the policy should be carried out in a long haul, the government would also struggle to plan the policy of echelon construction, especially the human resources; if a policy is not continuously executed, they cannot have expected results. Education industry requires insurance of stability and reduction of liquidity for the best result.

\subsection{Formulating feedback schemes positive for the nation's education and economic development in graduate education}

All the countries have problems with postgraduate education input. The results in the education input have been a problem especially concerned by many experts and scholars. One of the output targets in the well of graduate-students' education service trade is the level of effect-graduated students can bring to the homeland economy and education industry. At an early stage, the education consumer himself or the education-consuming destination has to prepay certain deal of money, energy and preparations in advance despite everything. Therefore, potential talents would only invest in the education industry and afterwards serve the country with what they have learned when a well-designed and thorough plan is made for postgraduate education. It 
should also be highlighted that by "feedback", it doesn't mean in narrow sense that the students work at home for creating value for the country. It in fact means, in broad sense, which graduates working around the globe also counts as long as they are contributing to their home country.

\subsection{The awareness of investment orientation in the trade of graduate education service}

Any under-development industry faces the problem of fund investment. This also applies when it comes to the trade of graduate service. The funds could directly affect the whereabouts of that industry. While contemplating the dispatching of budgets and funding, it should be taken into serious consideration at all times the role the choices of specific emphasis plays in the trade of graduate services. The decisions should more or less help to push the industry forward and go against all odds. Nevertheless, it does not imply in any way that all funding should be invested in it.

\subsection{Adjusting the integration of resource allocation and specialization}

Resource allocation including element like funds is crucial to the potential of an industry. Elements such as teaching team, software and hardware facilities, investment of education, open policies for education trades and backup support from related industries all belong to education trade resource. They are more or less in connection with the objectives of the service, types of service, the fund flow and so on. The allocation should keep up with all of these factors. Here are some examples for the statement above: for students in different majors, different teachers should be allocated to match the requirements; for special courses like Internet study, related facilities should be provided to support the objective conditions. Applying good resources to needed fields can make optimization of resource possible.

\subsection{Setting level of priority for master and doctor studies}

Master and doctoral education are two streams from postgraduate education. Customized concepts and resource allocation should be applied to these two different service trade objectives. Their distance in scale caused the ways the education is carries out; many countries set certain priorities for specific phase of the postgraduate studies. Some are very liberating during master's study while during doctoral study; students might gravitate to very detailed and specific research related to national core technology. Therefore, the policies for both phases are way beyond parallel. When conducting education services as such, those situations must be taken into serious consideration to avoid unnecessary loss. 


\subsection{Defining the relationship between the field and results of a research}

The trade of graduate education service is a comprehensive reflection of the input and output of the education service. Therefore, it is crucial to define the relationship between research area and results. The field of expertise one is working on shows possible results of the research. The results, on the other hand, reveals the very meaning of the field of research. The purpose of graduate education is not simply result-oriented but to count the entire process and various learning instruments, which are vital parts and the reward of the post-graduate education. It should be noticed how they resemble and how they differentiate, how they influence each other and how they together affect the education trade.

\subsection{Understanding the multi-layered connections in the streamline "produce-learn-study" of education service}

Three elements "produce, learn and study" are combined to as well as restrained by one another. If we observe countries with abundant education experience over the years such as the U.S. or Germany, we shall discover that they all have a very clear understanding of the connections among the three elements. However, theories should comply with practice. In the course of manufactory, new problems always keep coming. Therefore, institutes need to do research on them and thereafter seek solutions. Meanwhile, the suggested possible solutions should be tested repeatedly in practice, in the line of production. In this way, the nation's trade competitiveness will be improved. We are now in the age of information and we face the explosion of knowledge and economic development. These all made it especially serious that none of the three elements should be eliminated. Otherwise, the entire industry will be in threat. Only when the industry unveils the advantages of all three elements, could the purpose of win-win be achieved.

\subsection{Paying attention to the inclination of political factors interfering and taking over the leading role of cultural nexus}

The growth of graduate service trade transcends time and space, which means over time, most of the difficulties encountered along the way are realistic and easy to change. However, there is one thing we know for sure: graduate trade is an industry directly related to education business and culture. However, it should not be too politically overwhelmed. The reason of doing so is that the political factors of many cultural and economic conflicts end up standing in the way of education. There is even education production based on political relationship between countries. That weakens the very features of its cultural and service trades, a negative thing for the trade's plan of entering the market.

By comparing related factors of China, the United States, Germany, UK and Australia, the following table summarizes the ten factors of their countries. 
Table 1. The macro-micro factors

\begin{tabular}{|c|c|c|c|c|c|}
\hline & China & U.S. & Germany & U.K. & Australia \\
\hline Lingua Branch & Mandarin & English & German & English & English \\
\hline $\begin{array}{l}\text { Internationalization and } \\
\text { Localization: Education } \\
\text { Models }\end{array}$ & Developing & $\begin{array}{l}\text { Developed } \\
\text { International } \\
\text { System }\end{array}$ & $\begin{array}{l}\text { Developed } \\
\text { Independent } \\
\text { System }\end{array}$ & $\begin{array}{l}\text { Developed } \\
\text { Internation } \\
\text { al System }\end{array}$ & $\begin{array}{l}\text { Develop } \\
\text { ed } \\
\text { Indepen } \\
\text { dent } \\
\text { System }\end{array}$ \\
\hline $\begin{array}{l}\text { Long-term and Short-term } \\
\text { Policy planning and } \\
\text { Echelon Construction }\end{array}$ & $\begin{array}{l}\text { Plans: vague } \\
\text { Echelon } \\
\text { Con.: strong }\end{array}$ & $\begin{array}{l}\text { Plans: } \\
\text { distinct } \\
\text { Echelon } \\
\text { Con.: strong }\end{array}$ & $\begin{array}{l}\text { Plans: } \\
\text { distinct } \\
\text { Echelon } \\
\text { Con.: strong }\end{array}$ & $\begin{array}{l}\text { Plans: } \\
\text { distinct } \\
\text { Echelon } \\
\text { Con.: weak }\end{array}$ & $\begin{array}{l}\text { Plans: } \\
\text { vague } \\
\text { Echelon } \\
\text { Con.: } \\
\text { weak }\end{array}$ \\
\hline $\begin{array}{l}\text { Feedback from Graduate } \\
\text { Students }\end{array}$ & $\begin{array}{l}\text { Need: } \\
\text { strong }\end{array}$ & $\begin{array}{l}\text { Need: } \\
\text { weak }\end{array}$ & $\begin{array}{l}\text { Need: } \\
\text { weak }\end{array}$ & $\begin{array}{l}\text { Need: } \\
\text { weak }\end{array}$ & $\begin{array}{l}\text { Need: } \\
\text { strong }\end{array}$ \\
\hline Fund flow & unclear & $\begin{array}{l}\text { Mature } \\
\text { system }\end{array}$ & $\begin{array}{l}\text { Mature } \\
\text { system }\end{array}$ & $\begin{array}{l}\text { Mature } \\
\text { system }\end{array}$ & $\begin{array}{l}\text { Not } \\
\text { much }\end{array}$ \\
\hline $\begin{array}{l}\text { Categorization of } \\
\text { Resources and Integration } \\
\text { of professionalism }\end{array}$ & unstable & stable & stable & stable & $\begin{array}{l}\text { Relativel } \\
\text { y loose }\end{array}$ \\
\hline $\begin{array}{l}\text { Distinction between } \\
\text { Masters and Doctors }\end{array}$ & clear & $\begin{array}{l}\text { Somewhat } \\
\text { wholesome }\end{array}$ & clear & $\begin{array}{l}\text { Somewhat } \\
\text { wholesome }\end{array}$ & $\begin{array}{l}\text { Somewh } \\
\text { at } \\
\text { wholeso } \\
\text { me }\end{array}$ \\
\hline $\begin{array}{l}\text { Relationship between the } \\
\text { Field and Result of } \\
\text { Research }\end{array}$ & $\begin{array}{l}\text { Connected } \\
\text { but not well } \\
\text { defined }\end{array}$ & $\begin{array}{l}\text { Closely } \\
\text { connected }\end{array}$ & $\begin{array}{l}\text { Closely } \\
\text { connected }\end{array}$ & unclear & Unclear \\
\hline P-L-S Relation & $\begin{array}{l}\text { Fast-develop } \\
\text { ing but } \\
\text { immature }\end{array}$ & $\begin{array}{l}\text { Stably } \\
\text { developing }\end{array}$ & $\begin{array}{l}\text { Stably } \\
\text { developing }\end{array}$ & Unclear & Unclear \\
\hline $\begin{array}{l}\text { Cultural and Political } \\
\text { factors }\end{array}$ & $\begin{array}{l}\text { Certain } \\
\text { political } \\
\text { influences }\end{array}$ & $\begin{array}{l}\text { Certain } \\
\text { political } \\
\text { influences }\end{array}$ & $\begin{array}{l}\text { Certain } \\
\text { political } \\
\text { influences } \\
\text { but not much }\end{array}$ & $\begin{array}{l}\text { Certain } \\
\text { political } \\
\text { influences }\end{array}$ & $\begin{array}{l}\text { Insuffici } \\
\text { ent } \\
\text { political } \\
\text { influenc } \\
\text { es }\end{array}$ \\
\hline
\end{tabular}

\section{The macro-micro factors analysis}

Based on the aforementioned ten aspects, the following paragraphs shall carry out comparisons with China and some foreign countries that are famous for their graduate education. We divide it into two parts: the micro factors and the macro factors. 


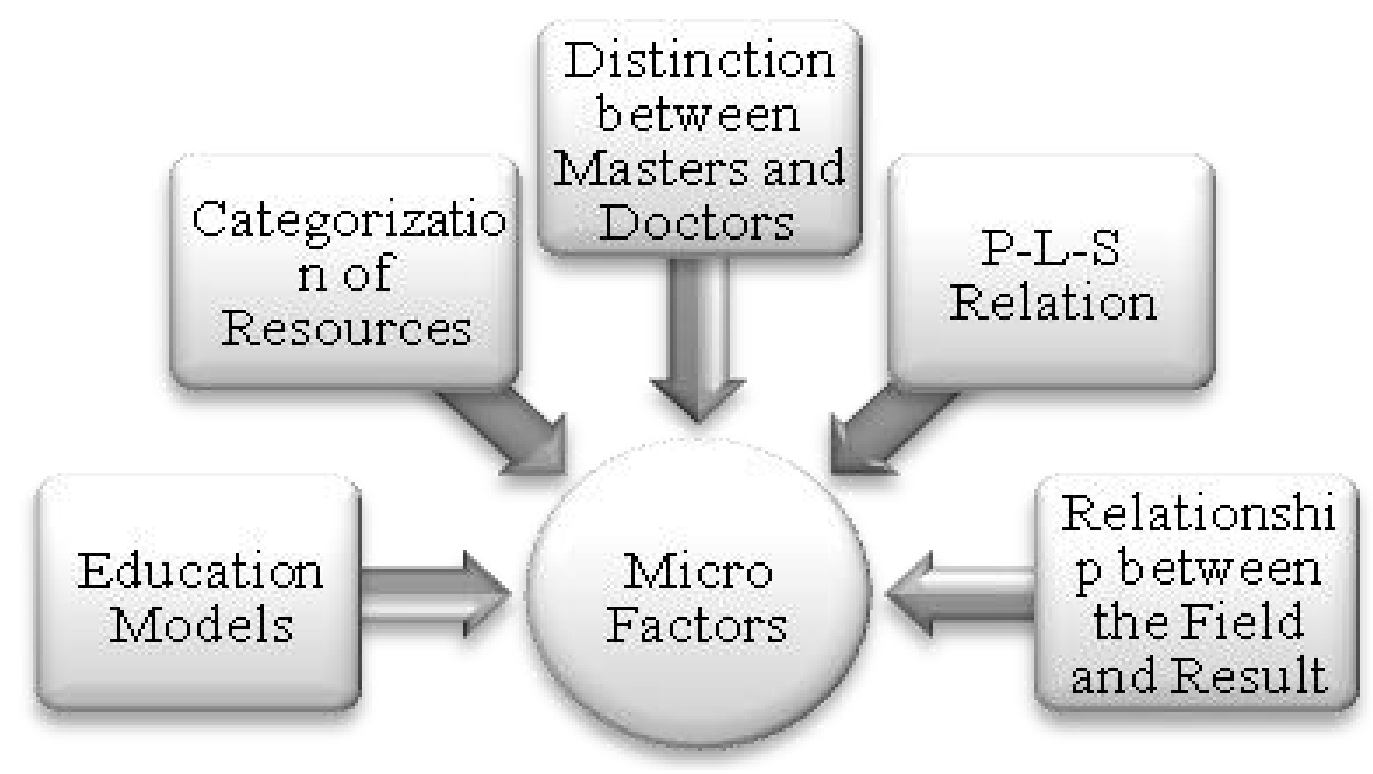

Figure 1: The micro factors

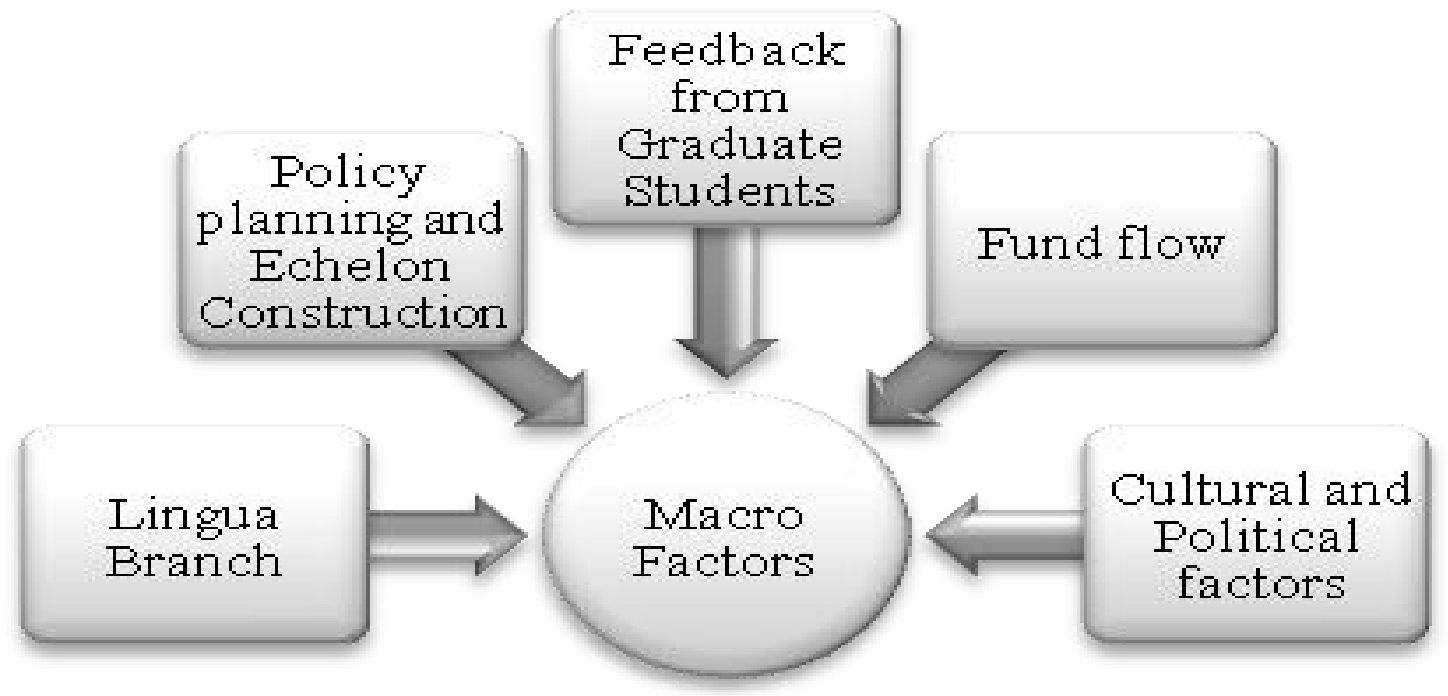

Figure 2: The macro factors

The evaluation system above suggests that in most index, China is behind other countries. Considering our nation's special conditions, education service trade is somehow held back in development. Therefore, we should stick to facts and make measurements in accordance with our current situation to improve competitiveness. We could take good advantage of the opportunities WTO has to offer and take active actions to increase the proportion of cooperative education on the one hand, to import high-quality resources, to learn from advanced modes, management, to absorb their education experience. On the other hand, the competitiveness of our education industry could only be increased when export ability is enlarged, the system reorganized and profession refinement finalized and education system revolution completed. This needs the country to invest more into education, switch the role of government, take more positive action to graduate education, make policies and regulations according to our 
conditions, clarify the whereabouts of the development of China's education service trade and furthermore pace up the process of the education reformation.

\subsection{Increase the proportion of co-operational education projects, import high-quality international education resources, learn from advanced operational modes and management abroad, absorb the experience and therefore strengthen and improve our graduate education system}

With the deepening of education reform, the education departments of government as well as many universities run schools according to their own definition and features since China's Reform and Open Policy. In political sense and practice, the specialness of co-operational education is very distinct. The education export in China are mostly composed of two kinds: international students coming to China for education and domestic students going abroad for further study. The government and many universities have already gained quite some achievements in several aspects: absorbing international students to choose to study in China among other options to enhance the making of certain policies, which helps, grow competitiveness of our education service industry, the introduction of advanced education mode and the perfection of graduate education system.

Our cooperation in running schools with other countries has come a long way in history. However, the cooperation on graduate education is still at the beginning phase. The undergraduate credits are only partially acknowledged abroad. This accreditation is casting negative influences on China's ability to attract students that are more international. Nevertheless, such problem is greatly relieved in terms of graduate education service trade.

Therefore, it would be a great option for us to study thoroughly cooperation on graduate education and to enlarge the capacity of majors available and scale of the projects. It is important to point out that the introduction of other countries' concepts and systems must be in appliance with actual conditions and policies in China; if this could work and students could acquire dual certificates then it is a big step forward as catalyst for nation's education reform in terms of graduate education system. Hence, the competitiveness of the education would increase.

\subsection{Increase the investment in education, transform government function, make more positive guidelines for education's future and matching policies and regulations to further increase the development of the education reform}

According to related statistics and predictions, there is a rising tendency that there will be more students going or coming from abroad studying on their own expenses. The scholarships applicable for undergraduates are less and less available these days. For undergraduate applicants, the situation has gone from everybody gets a scholarship to almost impossible to get even a semi scholarship. Education industrial nations such as 
U. K., Australia and New Zealand have a very systematic and wholesome education regulation for students. Meanwhile, China has brought enormous economic profits to education destinations overseas. Lately, Australian government has given positive response to the phenomenon of purchasing real estate property for financial support among Chinese students in Australia. Many universities overseas come to China for the promotion of their education when undergraduates had to face the hardship of finding a good employment or after high school students finished their National Entrance Exam. They would bring undergraduate and postgraduate plans or study plus employment package to attract the interest of Chinese students. This is a smart move showing the maturity of their education service industry and it provided valuable ideas this nation's education industry could learn from that.

\subsection{With the opportunity of Confucius Institute, we look forward to speeding up the pace of different aspects and globalize different facades of education while promoting our cultural to the world. This will eventually improve the competitiveness of education expert}

First, explain let the concept of a Confucius Institute. The institute is by no means a college but a non-profit organization for cultural exchange operated under universities and institutes overseas. One of the prime tasks of this institute is to provide Mandarin leaders all over the world standard and authoritative study materials of modern Mandarin and offer the most decent learning channels. On November 21, 2004, world's first Confucius Institute was established in Seoul, Korea. By November 2009, there had already been 282 Confucius Institutes and 272 Confucius classrooms in 88 countries and areas worldwide. More than 60 universities in China have cooperation with the Institute. Teaching supplies of the language exported to destination countries run these co-operations. Either these Chinese teachers are ones with professional training or they are volunteers. They became the platform of intercultural interactions. Confucius Institute is headquartered in Beijing and was first opened on April 9, 2007. The projects are operated on cooperation's between usually two nations. Confucius is the model of traditional Chinese culture. He was chosen to label the revival of our culture. The capital assigned in 1987 to establish the National Chinese Teaching Group, a.k.a. the "Hanban". That is where the Confucius Institute originated. Bringing forward the Chinese Culture to the gate of the world, Confucius Institute embodies Confucius' philosophy of "peace is most precious" and "harmony without uniformity".

\subsection{Observation of the change in WTO and control over the frontier of graduate education service trade}

Accession to WTO is complicated process. Policies and orientations keep changing all the time. The political standpoints of the government, the progression of phases a national economic body is in as well as the switch of role a country plays on the global stage. These all might affect the whereabouts of WTO. Education service trade, or, graduate education service, is an indispensible element in the development of a country. 
While visiting Germany on November 26, 2010, former Russian Prime Minister Vladimir Putin announced exploding news that "Russia is expected to join WTO by the end of next year. As researchers in the field, we should capture the information confirmed in his speech. Former Soviet Union has always had an intimate relationship in education with China. Setting aside the technical support at the beginning of modern China's history, many co-operations between two countries since the Reform and Open policy were firmly based on the mutual understanding of each other's education concepts. For regional reasons, our domestic scholars had many opportunities for academic exchange and education service in the north. However, China remained in disadvantage. According to Putin's remarks, we should make changes in "the 12th five-year plan" as well as in policy-making to adapt to the new trend.

Apart from other mutual profit-making and competitive relationships, we should make early outlook for the future in education industry. For instance, we could enroll more Russian students to come to China for graduate study, or, we can increase the quota of graduate students here learning Russian language. In terms of the northern region, limitations in education service should also be broken. Meanwhile, specialists could gather together to do research on the methods of opening the education service in Russia and predict the progress of the graduate service trade as well as analyzing the probability of compromising intercultural academic communication both ways.

\section{TAG}

In a word, foresight is necessary for observing the education industry. The above-mentioned examples are just some plausible suggestions. In action, we also need to consider many other factors to be the avant-garde in the industry.

Overall, to lift up the competitiveness of our nation's education service, there is still a lot for us to do. In hope of support from the government and help of specialists from different fields, we are certain that we could find a way just for us, bring it into practice, and eventually see the actual results.

\section{References}

Adugna, Lemi (2013) "Multilateral agreements and trade in education services: implications for Ethiopia", J. (ed.) Int. J. of Education Economics and Development, pp. $255-277$.

IDP (2006) "International Students in Australian Higher Education," Meeting of Higher Education Partners.

Larsen, Kurt, Martin, John P., Morris \& Rosemary (2002) "Trade in Educational Services: Trends and Emerging Issues”, J. (ed.) World Economy, pp.849-868. 
Larsen, K. \& Vincent-Lancrin S. (2002) "International Trade in Educational Services: Good or Bad?" J. (ed.) Higher Education Management and Policy, pp.9-46.

Li Jingxian \& Qu Shaowei (2006) "The Development and the Countermeasures of Our Country's Higher Education Service Consumption Abroad in Export Business," Journal of Educational Science of Hunan Normal University, pp. 51-53.

OECD (2004) "Internationalisation and Trade in Higher Education-Opportunities and Challenges," Meeting of Higher Education Partners.

Sehoole, C. T. (2004) "Trade in Educational Services: Reflections on the African and South African Higher Education System", J. (ed.) Journal of Studies in International Education, pp.297-316.

Shintaro, Hamanaka (2013), "International services trade, domestic regulations and reforms: The case of tertiary education of Japan", J. (ed.) Journal of International Trade Law and Policy, pp.204-225.

Wang, Y. F. \& WU, Q. J. (2006) "Discussion on the Overseas Consumption of International Education Service Trade in China - Current Situation and Countermeasures," J. (ed.) Journal of Shijiazhuang University of Economics, pp. 270-274.

Ye Yongling \& Zhang Lijun (2005) "Consideration on Trade in Education Services Under the WTO System," Higher Education Forum, pp. 177-180. 